\title{
Inflation Targeting and Real Exchange Rates in Emerging Markets
}

\author{
Joshua Aizenman \\ Department of Economics \\ University of California, Santa Cruz \\ Michael Hutchison \\ Department of Economics \\ University of California, Santa Cruz \\ and \\ Ilan Noy \\ Department of Economics \\ University of Hawai'i at Mānoa \\ Working Paper No. 08-10 \\ December 2008
}

\begin{abstract}
We examine the inflation targeting (IT) experiences of emerging market economies, focusing especially on the roles of the real exchange rate and the distinction between commodity and noncommodity exporting nations. In the context of a simple empirical model, estimated with panel data for 17 emerging markets using both IT and non-IT observations, we find a significant and stable response running from inflation to policy interest rates in emerging markets that are following publically announced IT policies. By contrast, central banks respond much less to inflation in non-IT regimes. IT emerging markets follow a "mixed IT strategy" whereby both inflation and real exchange rates are important determinants of policy interest rates. The response to real exchange rates is much stronger in non-IT countries, however, suggesting that policymakers are more constrained in the IT regime-they are attempting to simultaneously target both inflation and real exchange rates and these objectives are not always consistent. We also find that the response to real exchange rates is strongest in those countries following IT policies that are relatively intensive in exporting basic commodities. We present a simple model that explains this empirical result.
\end{abstract}

Keywords: Inflation targeting, real exchange rate, commodity exporters, emerging markets

JEL codes: E52, E58, F3

* We thank Mahir Binici, Nan Geng, Gurnain Kaur Pasricha and Kulakarn Tantitemit for helpful research assistance and Inessa Love for providing us her STATA routines. We are grateful to Scott Roger and Mark Stone for providing data. We also thank participants of the Research Seminar of the IMF, especially Herman Kamil, and participants of the Third NIPFA-DEA Program Meeting on Capital Flows Conference (New Delhi), especially our discussant Vincent Coen, for very helpful comments. 


\section{Introduction}

Inflation targeting is becoming a standard operating procedure for central banks around the world. By mid 2008, most central banks in the OECD countries ${ }^{1}$ and a growing number of developing economies had adopted inflation targeting. There is no international coordination to promote this monetary regime change, and countries do not join an internationally recognized monetary system nor follow common "rules of the game." Adopters of inflation targeting do so primarily because of the framework's perceived success in delivering low and stable inflation.

Despite its popularity, there is substantial controversy and mixed empirical evidence in the evaluation of the inflation-targeting framework. There are two main empirical approaches. The first approach focuses on the macroeconomic outcomes of countries following inflation-targeting regimes as compared to non-targeting countries. Although few argue that inflation targeting has harmful effects, there remains a vigorous academic and policy debate over whether the adoption of this monetary regime in advanced industrial countries has contributed to substantial declines in average inflation, lower inflation volatility and general macroeconomic stability compared to those countries not following inflation-targeting rules. The second empirical approach evaluating inflation-targeting (IT) policies focuses on central bank behavior under inflation targeting and non-targeting and how they operate in an IT environment. Even in this strand of the literature there is mixed evidence over whether formal adoption of an inflation targeting regime in advanced industrial economies substantively changes the behavior of central banks, and in particular their responses to inflation and output gaps.

This paper investigates the empirics of inflation targeting in emerging market economies within the context of the second strand of the literature-central bank operating behavior. We focus in particular on emerging-market central banks' responses to inflation, output gaps and real exchange rates using Taylor rule models (Clarida et al., 1998). Our aim is to distinguish between episodes when central banks are committed to an explicit inflation-targeting monetary regime and those periods of time when they are

\footnotetext{
${ }^{1}$ Fourteen of the 30 OECD countries have explicit inflation targets. However, twelve of these countries are in the EMU and operate under a single central bank (ECB). Hence, fourteen of the 19 "operational" central banks in the OECD target inflation.
} 
not (including central banks that have never followed inflation targeting). We focus on two factors critical to the conduct and control of monetary policy in emerging marketswide swings in the real exchange rate and the extent to which the countries are concentrated in commodity exports. We demonstrate, in the context of a simple illustrative model, that these distinguishing characteristics are in principle important in designing the form of the monetary policy rule. In particular, when a country is experiencing large real exchange rate shocks that can affect potential outputcharacteristic of emerging markets - a modified version of inflation targeting dominates a pure inflation targeting strategy.

Our empirical work is based on panel-data so as to distinguish between group characteristics, respectively, of the inflation-targeting and non-targeting central banks. We develop an empirical model that investigates the nature of inflation targeting strategies followed in emerging markets. We characterize inflation targeting strategies in the context of a modified Taylor rule operating procedure, and demonstrate that this rule varies markedly from non-targeting emerging markets (as well as inflation-targeting industrial countries). Moreover, our focus is on the role of the real exchange rate in the policy rule and how this is affected by the countries' exposure to commodity-intensive production (and, hence, terms-of-trade shocks).

Four factors motivate our empirical research. Firstly, the great bulk of the research in this area is concerned with inflation targeting in advanced industrial countries and relatively little research addresses the particular features of inflation targeting in emerging markets ${ }^{2}$. This is a shortcoming in the literature since there are many reasons that emerging markets may differ from industrial countries in the approach to inflation targeting. These reasons include different institutional arrangements, especially those relating to the credibility and political independence of the central bank, different inflation and macroeconomic experiences, different exposures to terms-of-trade shocks, and different levels of financial development. Fraga et al. (2003), for example, argue that inflation targeting in emerging markets has been successful overall, but not as successful as in developed economies, largely because of challenges associated with weak

\footnotetext{
${ }^{2}$ Some exceptions are IMF (2005), Conçalves and Salles (2008), Schmidt-Hebbel (2002), Mishkin and Schmidt-Hebbel (2007), Corbo et al. (2001) and Edwards (2006).
} 
institutions, limited credibility and large external shocks. Aghion et al. (2006) demonstrate that countries with relatively less developed financial sectors are more likely to suffer output losses associated with exchange rate volatility. In this case, greater concern for real exchange rate volatility may lead central banks in emerging marketscountries with lower levels of financial development than industrial countries - to follow a monetary policy rule (Taylor rule) that captures some form of target inflation, output deviations from the natural rate and real exchange rate fluctuations.

Secondly, our emphasis is on introducing real exchange rate fluctuations into the inflation-targeting framework. Real exchange rates are likely to play an important role in the formulation of optimal monetary policy in emerging markets, as shown theoretically in our illustrative model (appendix A), and we examine this connection in our estimations of de facto policy rules. Thirdly, the distinction between heavily concentrated commodity-exporting emerging markets and non-concentrated emerging markets is potentially important in how inflation targeters work in practice. We explore this distinction. Fourthly, we follow a panel methodological approach in examining these issues. Other studies in this area have relied upon individual country time-series analysis. A panel analysis provides some advantages since it allows clear focus on characteristics of policy rules common to inflation-targeting countries treated as a group and allows us to distinguish them from non-inflation targeting countries.

Our results indicate that the publically announced adoption of inflation targeting strategies by central banks in emerging markets, often with much fanfare, is a substantive deviation from past monetary policy formulation and sharply different from non-targeting emerging markets. As our theoretical model predicts, however, inflation targeting emerging markets are not following "pure" inflation targeting strategies. Rather, we find that external variables play a very important role in the policy rule - inflation-targeting central banks in emerging markets systematically respond to the real exchange rate. Of the inflation targeting group, those with particularly high concentration in commodity exports change interest rates much more pro-actively to real exchange rate changes than do the non-commodity intensive group. Overall, our results are robust to a variety of model formulations and estimation strategies. 
The next section discusses the inflation targeting literature as it applies to emerging markets, and highlights the gap in the empirical literature which we address in our contribution. Section 3 presents the data, descriptive statistics and empirical model. Section 4 presents the empirical results and section 5 concludes. Appendix A presents the theoretical model that motivates our empirical formulation of the policy rule equations.

\section{Inflation targeting in emerging markets}

There is a large empirical literature on inflation targeting, most of which focuses on advanced industrial countries. These studies generally take one of two approaches. The first approach measures the effects of inflation targeting on inflation, inflation volatility, and other macroeconomic variables. The second approach focuses on characterizing central bank operating procedures, attempting to distinguish between policy functions of inflation targeting countries and those not targeting inflation. Studies in the first strand of the empirical literature employ both individual country time-series and multi-country panel methods, while the second strand of literature is almost exclusively focused on individual country time-series.

\section{Macroeconomic Effects of inflation targeting}

Empirical studies generally find mixed results on the effects of inflation targeting on inflation and other macroeconomic variables. For example, Johnson (2002) undertakes a panel study consisting of five IT (Australia, Canada, New Zealand, Sweden and the United Kingdom) and six non-IT advanced industrial countries. He finds that the announcement of inflation targets materially lowers expected inflation (controlling for business cycle effects, past inflation and fixed effects). Also in the context of a panel regression framework, Mishkin and Schmidt-Hebbel (2007) similarly conclude that inflation targeting does make a difference in advanced industrial countries by helping them achieve lower inflation in the long run and have smaller inflation responses to oil and exchange rate shocks. However, the results for advanced country inflation-targeters 
are very similar to their high-performing country control group. ${ }^{3}$ Rose (2007) argues that inflation targeting is a very durable (long-lasting) regime compared to other monetary regimes and that inflation targeters have both lower exchange rate volatility and less frequent "sudden stops" of capital flows. ${ }^{4}$ By contrast, Ball and Sheridan (2005), in a cross-section investigation, reject any long-term differences between advanced industrial inflation targeters (seven countries) and non-targeters (thirteen countries).

The experience and relative success of emerging markets with inflation targeting is somewhat more supportive, although relatively little empirical work has explored this issue. Mishkin and Schmidt-Hebbel (2007) find that inflation targeting in emerging countries performs less well than in advanced industrial countries, although the pre- and post-inflation targeting reductions in inflation in emerging markets are substantial. ${ }^{5}$ The IMF (2005), using the methodology of Ball and Sheridan (2005), presents results of a study focusing on 13 emerging market inflation targeters compared with 29 other emerging markets. They report that inflation targeting is associated with a significant 4.8 percentage point reduction in average inflation, and a reduction in its standard deviation of 3.6 percentage points relative to other monetary strategies. Conçalves and Salles (2008) also apply the methodology of Ball and Sheridan (2005) to a 36 emerging market economies. Similar to the IMF study, they find that adoption of an inflation targeting regime leads to lower average inflation rates and reduced output growth volatility compared to a control group of non-targeters. A recent edited volume published by the OEDC (De Mello, 2008) on inflation targeting in emerging markets, focusing mainly on individual country case studies, also finds quite positive outcomes associated with the adoption of IT regimes.

\footnotetext{
${ }^{3}$ Thirteen advanced industrial countries that "... are at the international frontier of macroeconomic management and performance.” (p. 4)

${ }^{4}$ Rose (2007) considers a broad group of advanced industrial and developing countries in his empirical work.

${ }^{5}$ The authors do not consider a control group of emerging countries that are not targeting inflation.
} 


\section{Policy Functions in IT Regimes}

In terms of central bank policy functions, Clarida, Gali and Gertler (1998) focus on six major industrial countries and suggest that the G3 (Germany, Japan and U.S.) have followed an implicit form of inflation targeting since 1979. The main evidence for this conclusion is that these central banks are forward looking, and respond to anticipated as opposed to lagged inflation. Clarida et al. (1998) argue that the success of the G3 in lowering inflation and keeping inflation at a low level may be attributable to this implicit inflation-targeting policy. They conclude that inflation targeting may be superior to fixing exchange rates as a nominal anchor (as was prevalent in their sample period for the E3 countries of France, Italy and the United Kingdom). They found the response to real exchange rates is significant and of the expected sign, but small in magnitude for Germany and Japan.

Other studies have investigated differences in IT and non-IT policy regimes by explicitly estimating "Taylor rule" equations for individual countries. A number of studies in this genre, focusing on advanced industrial countries, find some evidence that countries are following significantly different policy rules in IT regimes (e.g. Mohanty and Klau, 2005; Edwards, 2006; Corbo et al., 2001). For example, Corbo et al. (2001) find somewhat mixed evidence for seventeen OECD countries estimated individually. They find that inflation targeters exhibit the largest inflation gap coefficient (response to inflation) relative to the output gap coefficient (response to output), although in most cases the coefficients are not statistically different from zero. Lubik and Schorfheide (2007, JME) estimate a calibrated small-scale GE model for a small open economy using data for Australia, Canada, New Zealand and the United Kingdom over 1983 to 2002 (quarterly data). They consider Taylor-type rules, where the authorities respond to output, inflation and exchange rates. They find that Australia and New Zealand change interest rates in response to exchange rate movements, but that Canada and the United Kingdom do not respond to exchange rates.

Dennis (2003) investigates several models for the Australian experience and finds that the authorities should optimally focus not just on inflation but also on real exchange rate fluctuations and terms of trade when they set interest rates to the extent that import goods are consumption goods (and enter into CPI). Ravenna (2008) considers the 
Canadian case with IT targeting. He estimates a DSG model and is able to determine whether the good inflation performance of Canada since adopting an IT regime is due to the IT policy or to "good luck." He finds that low average inflation since adopting the IT regime is associated with the credibility of policy under this regime. However, the lower volatility of inflation is mainly associated with "good luck" in that few major adverse shocks have impacted the Canadian economy during this period.

Other studies suggest that monetary policy operating procedures do not fundamentally change with the move to an IT regime. Drueker and Fischer (2006), for example, find "no difference" in the monetary policy rules followed by IT countries and comparable non-IT countries in their own empirical work, and at best mixed evidence supporting any substantive difference in numerous studies in their survey of the subject. They estimate individual country time-series regressions and compare high-performing advanced industrial countries that are following an IT regime and those that are not.

\section{Policy Rules in Emerging Markets, Real Exchange Rates and Commodity Export Concentration}

Only a few empirical studies focus on central bank reaction functions in emerging markets, and this is done on a case by case basis. Schmidt-Hebbel and Werner (2002) apply common empirical framework (VAR models) to compare the experiences of Brazil, Chile and Mexico with inflation targeting. They estimate Taylor rule equations for each country with the real interest rate as the dependent variable. Only for Brazil is the expected inflation gap statistically significant, whereas only for Chile is the output gap statistically significant. They do find that the trade surplus (lagged) enters negatively and significantly in most cases (i.e. trade surplus leads to decline in real interest rate) and that this effect dominates all other variables. They find that these countries continue to respond to exchange rate changes in the short-term, if not the medium-term, and characterize them as "dirty" floaters. ${ }^{6}$

\footnotetext{
${ }^{6}$ One drawback of these time-series regressions is the very short sample periods. The authors use monthly data for Brazil and Mexico, and quarterly data for Chile.
} 
Cordo et al. (2001) estimate Taylor-rule type equations for eight emerging-market economies over 1990-1999 using quarterly data. They classify countries during the 1990s as IT, potential IT and non-IT. ${ }^{7}$ Two emerging markets are in their IT category (Chile and Israel), five are in the potentially targeting category (South Africa, Brazil, Colombia, Mexico and Korea) and one is in the non-IT category (Indonesia). In the IT and potential IT categories, four (two) central banks appear to respond to inflation (output) deviations from target in setting interest rates. The authors do not test, in their Taylor rule estimates, whether central banks in emerging markets consider external variables.

Mohanty and Klau (2004) estimate modified Taylor rules for 13 emerging market and transition economies, complementing inflation, the output gap and lagged interest rates with current and lagged real exchange rate changes. They find that the coefficients on real exchange rate changes are statistically significant in ten countries (OLS estimates), with the significant contemporaneous effect ranging from -0.33 (Brazil) to 0.35 (Chile). The policy response to exchange rate changes is frequently larger than the response to inflation and the output gap. They conclude that this supports the "fear of floating” hypothesis. Mohanty and Klau (2004) do not explicitly address the inflation targeting issue in this context, but it is apparent that these countries, whether or not they profess to follow an IT regime, are attempting to stabilize real exchange rates as well as control inflation and stabilize output.

Edwards (2006) investigates the determinants of the exchange rate response in the Taylor-rule regressions, building on the work by Mohanty and Khau (2004). He runs cross-country regressions of the exchange rate coefficient on several explanatory variables (each regression with 13 observations). Edwards (2006) finds that countries with a history of high inflation, and with historically high real exchange rate volatility, tend to have a higher coefficient (response) to the real exchange rate in Taylor rule equations.

De Mello and Moccero (2008) estimate interest rate policy rules for four Latin American emerging markets_-Brazil, Chile, Colombia and Mexico—characterized by

\footnotetext{
${ }^{7}$ They estimate one equation for each country over the 1990s. Hence, in most cases, their estimated coefficients average periods of both inflation-targeting and non-targeting for countries that eventually adopted an IT regime.
} 
inflation targeting and floating exchange rates in 1999. They estimate an interest rate policy function in the context of a New Keynesian structural model with equations for inflation, output and interest rates. They find inflation targeting, in a post-1999 regime, has been associated with stronger and persistent responses to expected inflation in Brazil and Chile. Mexico is the only country they find where changes in nominal exchange rates were found to be statistically significant in the central bank's reaction function during the IT period.

\section{Importance of Real Exchange Rates for IT Regimes in Emerging Markets}

The theoretical importance of the real exchange rate to the conduct of monetary policy in an IT regime is presented in appendix A. We illustrate these considerations in a simplified version of Ball (1999), where the policy maker is concerned about exchange rate volatility. The wish to mitigate exchange rate volatility follows the logic of Aghion et al. (2006), who show that exchange rate volatility reduces potential output (or output growth rate) in developing countries, attributing it to financial channels. The adverse effect of volatility may be the outcome of increasing the expected cost of funds in circumstances where agency and contract enforcement costs are prevalent, the financial system is shallow, and trade openness is significant. ${ }^{8}$ These conditions tend to be exacerbated in developing countries relying heavily on mineral and commodity exports.

We simulate a simple model that confirms that a greater weight on mitigating exchange rate volatility tends to increase the responsiveness of the policy rule to exchange rate changes, possibly with sizable welfare effects. Given these considerations, we test the degree to which the policy rule adopted by IT commodity-intensive developing countries

\footnotetext{
${ }^{8}$ A growing literature has identified financial intermediation, in the presence of collateral constraints, as a mechanism explaining the hazard associated with credit cycles induces by shocks. The prominent role of bank financing in developing countries suggests that balance sheet valuation problems associated with shocks may lead to higher cost of borrowing, reducing average growth, and possibly to recessions in the aftermath of adverse shocks. In these circumstances, real exchange rate changed induced by adverse terms of trade shocks or contagion may impose adverse liquidity shocks, propagating lower output growth. This channel is of greater potency in countries where most financial intermediation is done by banks, relying on debt contracts. Less efficient judiciary, higher monitoring and enforcement costs tend to magnify the adverse impact of real exchange shocks on the costs of credit; for further references and models of the credit channel in developing countries see Aghion et al. (2006) and Aizenman (2008).
} 
differs from that of the IT non-commodity exporters, finding support to the greater sensitivity of commodity IT countries to exchange rate changes. Moreover, an IT rule responding to the exchange rate may be supplemented by a corresponding international reserve policy (Aizenman and Riera-Crichton, 2007). Our empirical specification also considers this possibility by controlling for changes of international reserves.

\section{Data}

As we detail in the introduction, our focus is on emerging markets. We classify emerging markets using the list of countries included in Morgan Stanley's MSCI Emerging Markets Index. The 16 countries in our dataset are: Argentina, Brazil, Colombia, Czech Republic, Hungary, Indonesia, Israel, Jordan, Korea, Malaysia, Mexico, Morocco, Peru, Philippines, Poland and Thailand (Appendix B) ${ }^{9}$. The data sample was restricted by using quarterly data (annual data provides a much larger group of countries) and by countries that use nominal interest rates as a primary operating instrument of monetary policy.

We rely on Mishkin and Schmidt-Hebbel (2007) to identify the monetary regime and the exact start date of inflation targeting ${ }^{10}$. We collect quarterly data for these 16 emerging market countries for 1989Q1 to 2006Q4. ${ }^{11}$ We delete from our dataset hyperinflationary periods (annual inflation higher than 40\%). Our primary source for data is the IMF's International Finance Statistics CD-ROM, more details are provided in the data appendix (Appendix C).

\footnotetext{
${ }^{9}$ Chile was excluded from the data set because the country's policy functions appear anomalous to the other IT countries in the sample. Chile appears to be following a real interest rate policy function. Corbo et al. (2001) estimate Taylor rules for 25 countries and only in the case of Chile do they estimate a real interest rate equation. Similarly, we find Chile to be an outlier in our panel-data Taylor rule regressions, even when including fixed effects in the estimation procedure. ${ }^{10}$ The IT start dates given by Rose (2007) are almost identical.

${ }^{11}$ The Transition economies only have available data starting in the beginning of the 1990s.
} 


\section{Methodology and Results}

\section{Preliminaries}

Table 1 describes the main variables we examine and their descriptive statistics for our sample of emerging markets. The first column shows the mean and standard deviation for those country-quarter observations in which an inflation-targeting regime was in place. The second column includes the sample of observations consisting of countries who never adopted an IT regime and IT countries before their adoption of an IT regime. GDP growth is virtually the same in the IT and non-IT samples, while inflation is about half of the level on average in IT regimes (5.4 percent) compared to non-IT regimes (9.6 percent). The average level of nominal interest rates is 3.7 percentage points less in the IT sample compared with the non-IT sample, a somewhat smaller difference than the 4.2 percentage point difference in inflation rates between the two regimes, indicating somewhat higher average short-term real interest rates in the IT sample.

The external variables indicate that IT emerging markets appear to experience a substantially higher rate of average depreciation of the real exchange rate and lower rate of international reserve accumulation. This suggests less exchange rate management on the part of the IT countries. Due to the large variability of the sample observations, however, none of these differences are statistically significant using standard thresholds.

In order to examine the time-series properties of our data and assess the appropriate estimation methodology we conduct panel unit root tests (Appendix D). We employ the panel unit root tests described in Levin et al. (2002) and Breitung (2000) and reject unit roots for all of our time series using at least one or both of these tests. ${ }^{12}$

\section{Taylor Rule Regression Results}

Following an extensive literature that originates from Taylor (1993), we assume a monetary policy reaction function of the following form:

$i_{t}=\rho i_{t-1}+\alpha\left(y_{t}-y^{*}\right)+\beta\left(\pi_{t}-\pi^{*}\right)+\gamma X_{t}$

\footnotetext{
${ }^{12}$ As documented by Enders (2003) and others, panel unit root tests are quite sensitive to a number of data characteristics and are difficult to interpret.
} 
As is standard in this literature, we assume the authorities, in setting the policy interest rate, react to both the output gap and the inflation gap. In addition, following English et al. (2002), we assume a policy smoothing goal that manifests in a lagged interest rate on the RHS. The main focus of this paper, however, are a set of possible external variables $\left(X_{t}\right)$ that may also be part of the policy reaction function. Our estimation equation for a panel of 16 emerging-market countries is:

$i_{i, t}=\mu_{i}+\rho i_{i, t-1}+\alpha\left(y_{i, t}-y_{i}\right)+\beta \pi_{i, t}+\gamma X_{i, t}+\varepsilon_{i, t}$

The inflation target variable $\left(\pi^{*}\right)$ is assumed to be time invariant for each country and is subsumed in the country fixed-effect $\left(\mu_{i}\right)$ parameter.

Table 2 presents the estimates for the benchmark Taylor rule regressions employing a fixed-effects least-squares estimation procedure (LSDV). ${ }^{13}$ Column (1) and (4) presents the benchmark model without external variables for the IT and non-IT samples, respectively. The other columns extend the benchmark to the external variables. Columns (2) and (5) combine the benchmark model with the percentage change in the real exchange rate, and columns (3) and (6) combine the benchmark model with the percentage change in international reserve holdings.

The model explains much of the variability in interest rates, with explanatory power ranging from $73-80 \%$ (adjusted $\mathrm{R}^{2}$ ). The degree of persistence, measured by the lagged interest rate coefficient, is quite high. The persistence in the IT group is marginally higher than in the non-targeting group. The coefficient on inflation is highly significant, large and stable (with a narrow 0.22-0.29 range) in the inflation-targeting regime but not generally in the non-IT regime. Given the estimated impact effects and persistence, the long-term response for the IT targeters to a one percentage point rise in inflation is to increase interest rates by between 1.4-1.7 percentage points. Non-IT policymakers do not respond to inflation rates in the same pronounced and significant

\footnotetext{
${ }^{13}$ It is well known that the LSDV estimation with a lagged dependent variable is biased when the time dimension of the panel (T) is small. Nickell (1981) shows that this bias approaches zero as T approaches infinitely. Judson and Owen (1999), in a Monte Carlo study, shows that the LSDV estimator performs well in comparison with GMM and other estimators when $T=30$. In an unbalanced panel with T=30, LSDV performs best. $\mathrm{T}$ is equal to 68 on our study and the bias is presumably small.
} 
way that their IT counterparts do, i.e. the impact response of 0.15 implies a 0.58 percentage point long-term response in the non-IT group. The output gap is not significant in any of the regressions. ${ }^{14}$

The external variables are also very important in distinguishing the operating procedures of the IT and non-IT groups. Both IT and non-IT emerging market central banks respond to real exchange rates in setting interest rates-- the coefficients are large and highly statistically significant. It is noteworthy, however, that the real exchange rate response is much smaller in the IT countries $(0.07)$ compared to the non-IT countries (0.13). The IT group attempts to "lean against the wind" and stabilize the exchange rates by increasing interest rates in response to real exchange rate depreciation, but their actions are apparently more constrained by the commitment to target inflation than the non-IT group in how proactively this objective is pursued. In a similar vein, it is only the non-IT group that takes into account changes in international reserves in setting interest rates. In particular, a one percent increase in reserves leads to a 6 basis point decline in domestic short-term interest rates for non-IT countries (23 basis point long-run effect). Only the non-IT group eases policy in response to international reserve inflows.

Table 3 investigates whether the response of policy interest rates to real exchange rates is also related to the degree of trade openness. From our theoretical discussion, we expect countries that are more open to trade to be more vulnerable to real exchange rate changes and this in turn would affect their response in setting interest rates. We test this hypothesis by including a term capturing the interaction of trade openness and real exchange rate change.

Column (2) presents the baseline results for the IT group. ${ }^{15}$ The interest rate response to real exchange rates of the IT group does not appear to be affected by the

\footnotetext{
${ }^{14}$ The output gap is not a significant variable in practically any of the regressions we ran. For robustness, we also estimated the benchmark regressions using the Clarida (2001) specification that includes both contemporaneous and lagged inflation as independent variables. Results on the magnitude of the effect of inflation on the interest rate are practically the same.

${ }^{15}$ The model specifications in columns (1) and (3) were reported in Table 2 and are included in Table 3 for purposes of comparison. The results differ slightly from Table 2 due to fewer included observations. A common set of observations were employed in Table 3 for the IT and
} 
degree of trade openness and the estimated coefficients on the other variables are nearly identical to the specifications reported in Table 2.

Column (5) in Table 3 reports the results for analogous specification of non-IT group. Firstly, this specification provides strong evidence of a significant interest rate response to inflation for the non-IT group. This response is less that half of that of the IT group, but highly statistically significant. A one percentage-point rise in inflation leads to an 11 basis point rise in the nominal interest rate (50 basis point long-term response). Secondly, the interest rate response to real exchange rate changes is less in the non-IT group the larger is the degree of trade openness. This effect is significant, robust and economically important. For example, a non-IT country that has a trade openness measure of 0.50 (export plus imports divided by GDP) will raise interest rates by about 115 basis points in response to a 10 percent rise (depreciation) in the real exchange rate. This response falls as the degree of trade openness increases. If countries are open to trade, they are also more likely to be open to international capital movements. In this case, they may have less control over domestic interest rates and limited ability to respond to real exchange rate changes. This effect may dominate their desire to stabilize the economy by more aggressively responding to real exchange rate changes.

We include the reserve change variable to the equation in columns (3) and (6) of Table 3 for the IT and non-IT observations, respectively. A rise of reserves appears to lead to lower interest rates in non-commodity IT countries and no response in the commodity IT group. The other results are unchanged.

\section{Commodity Exporters}

Our theoretical discussion emphasizes the critical role of "external vulnerability" in the setting of policy interest rates in emerging markets. External vulnerability in turn is likely to be magnified if countries are significant commodity exporters. These countries

non-IT regressions, and inclusion of the trade openness variable reduced the number of available observations. 
are much more vulnerable to terms-of-trade shocks and real exchange rate shocks, ${ }^{16}$ and would presumably place greater emphasis on stabilizing the real exchange rate when they set interest rates.

To address this issue, we divide our IT sample into commodity exporters and noncommodity exporters. Summary statistics for the commodity exporting and noncommodity exporting IT countries are reported in Table 4 and policy equations are reported in Table 5. Average inflation is higher and interest rates are substantially higher in the commodity-exporting group, while the other variables of interest are quite similar to the non-commodity exporting group. In particular, average real exchange rate depreciation and the average percentage growth in international reserves is not significantly different between the two groups.

The interest rate policy equation estimates, as theory suggests, are very different for the commodity and non-commodity IT countries. In particular, shown in Table 5, the commodity-intensive exporting countries follow a much stronger leaning-against-thewind exchange rate policy. ${ }^{17}$ The real exchange rate response (point estimate) is statistically significant and positive in both commodity and non-commodity countries, but the degree of response is almost twice as large in the commodity group. In particular, ten percent depreciation in the real exchange rate causes the commodity-intensive central banks to increase short-term interest rates by 110 basis points, while the non-intensive central banks increase interest rates by 50 basis points.

\footnotetext{
${ }^{16}$ In preliminary work, we also considered policy rules with terms-of-trade shocks entered explicitly into the estimation equation. The difficultly was in obtaining an accurate terms-of-trade measure. We considered three measures of terms-of-trade: From the International Monetary Fund's International Finance Statistics, from Datastream, and a TOT measure used by International Monetary Fund staff internally for the calculations presented in the World Economic Outlook. These measures were not significantly correlated with each other, despite purporting to measure the same phenomenon (see appendix D. In addition, none of these measures were statistically significant when included in the interest rate policy equations. We have little confidence in the reliability of these terms-of-trade measures, although all are derived from official sources, and do not report statistical results where they are included.

${ }^{17}$ The basic Taylor equation model is estimated with the addition of real exchange rates in Table 5 for IT countries, separating the sample into commodity-intensive and non-intensive countries. Reserve changes for the IT countries were not significant in Table 3 or Table 5, and are not reported for brevity.
} 
Surprisingly, only the commodity-intensive countries appear to be following an IT policy - despite the two samples including only IT observations. In particular, the response to inflation is only significant in the commodity-intensive group equation. The point estimate indicates that a one percent rise in inflation leads to an 83 basis point increase in the nominal interest rate. The response of the non-commodity exporting group to inflation, despite an official IT policy regime, is not statistically significant.

It is noteworthy that the strong response to inflation of the commodity-intensive IT group, and apparently weak response of the non-commodity intensive group, is probably not because they have radically different histories of inflation or credibility. That is, we do not think the differences in results are because the non-commodity IT group are "superior" inflation targeters, with so much credibility with the public that they do not need to respond to short-term fluctuations in inflation. In particular, the inflation rate of the non-commodity IT group is 4.8 percent, lower than the commodity IT group average but nonetheless substantial. ${ }^{18}$

\section{Simultaneity and Varying Inflation Targets}

Policy-rule estimation in a panel-setting with lagged dependent variables may lead to estimation bias. We deal this issue by following the Hausman and Taylor (1981) estimation procedure. This procedure takes into account bias in estimation of panels with predetermined and/or endogenous variables. Moreover, we have assumed that to this point that the inflation targets were constant in every IT country. We address this issue by substituting inflation by deviations of inflation from the inflation target (collected from various central bank publications).

The Hausman-Taylor (H-T) three-step estimation methodology is an instrumental variable estimator that takes into account the possible correlation between the disturbance term and the variables specified as predetermined/endogenous. The methodology requires distinguishing between those control variables that are assumed to be (weakly) exogenous

\footnotetext{
${ }^{18}$ All inflation data are annualized quarterly rates.
} 
and those that are assumed to be predetermined/endogenous and thus correlated with the country specific effects. We assume that only the GDP gap variable is exogenous.

In the first step of the $\mathrm{H}-\mathrm{T}$ estimation, estimates from a country-fixed-effects model are employed to obtain consistent but inefficient estimates for the variance components for the coefficients of the time-varying variables. In the second step, an FGLS procedure is employed to obtain variances for the time-invariant variables. The third step is a weighted IV estimation using deviation from means of lagged values of the time-varying variables as instruments. The exogeneity assumption requires that the means of the exogenous variables will be uncorrelated with the country effects. ${ }^{19}$

Under the plausible exogeneity assumption described above, the H-T procedure provides asymptotically consistent estimates for dynamic panels, but it is not the most efficient estimator possible. More efficient GMM procedures rely on utilizing more available moment conditions to obtain a more efficient estimation (e.g., Arellano and Bond, 1991). These, however, are typically employed in estimation of panels with a large number of individuals and short time-series and in our case of small-N large-T the number of instruments used will be very large (and the system will be vastly overidentified; see Baltagi, 2005). This will make the results unstable and difficult to interpret (see Greene, 2007).

Columns (1) and (3) of Table 6 reports the results using the H-T estimation procedure and using deviations from the time-varying inflation target for the IT commodity and IT non-commodity countries. (These equations are analogous to Table 5). Firstly, it is noteworthy that estimates for the inflation gap from target response in Table 6 for the IT commodity and IT non-commodity countries are larger than inflation response reported in Table 5. The impact (long-term) response of inflation from target for the commodity IT countries is to raise interest rates by about 0.88 (4.9) percentage points in Table 6 and 0.88 (2.8) percentage points in Table 5. These estimates suggest substantial short-run and long-run responses in nominal interest rates, and a substantial long-run response in real interest rates, to an increase in inflation in the IT commodity-

\footnotetext{
${ }^{19}$ Identification in the Hausman-Taylor procedure requires that the number of exogenous variables be at least as large as the number of time-invariant predetermined/endogenous variables.
} 
intensive countries. Secondly, the output gap is highly significant in columns (1) and (3), contrasting sharply with the results presented in Table 5. Thirdly, the real exchange rate change variable coefficient is highly statistically significant and almost identical in magnitude in columns (1) and (3). This differs from Table 5 where the estimated response in the commodity IT countries is much larger in magnitude compared to noncommodity IT countries.

Finally, we include changes in international reserves in the second and fourth columns of Table 6 . The change in international reserves is only significant in the noncommodity IT countries, suggesting that a rise in reserves is associated with a rise in interest rates.

Are IT countries using the real exchange rates as an indicator of future inflation?

Our results suggest that external factors are important even for inflation targeting policymakers. Central banks operating under inflation targeting regimes in emerging markets react to current monetary conditions and current inflation as well as to changes in real exchange rates. However, this observation does not necessarily imply that IT policymakers have policy targets other than inflation, such as the setting of a specific real exchange rate. It is possible that policymakers observe changes in current real exchange rate as an indicator of future inflation and therefore react to it contemporaneously. ${ }^{20}$ In order to better understand the dynamics between inflation, real exchange rate and interest rates, we estimate a reduced-form vector autoregression model (VAR):

$z_{i, t}=\mu_{i}+\Gamma z_{i, t-\phi}+e_{i, t}$

With the three-variables vector $z_{i, t}$ composed of inflation, real exchange rate change, and the change in the terms of trade. We estimate a reduced-form VAR but also exploit our panel to account for country specific but time invariant relationships between the three components of the vector $z_{i, t}$. In applying the VAR procedure to panel data, we follow Love and Zicchino (2006). A panel structure imposes the restriction that the underlying relationships are equivalent for all countries. A way to partially overcome the restriction

${ }^{20}$ Clarida (2001) discusses this issue in the context of a forward-looking IT regime. 
on equivalent parameters is to allow for country-heterogeneity in the time-invariant coefficients (i.e., the fixed effects - $\mu_{i}$ ). Because the fixed effects are correlated with the regressors, due to lags of the dependent variables, the mean-differencing procedure commonly used to eliminate fixed effects would create biased coefficients. To avoid this problem the methodology we use removes the forward mean, i.e. the mean of all the future observations available for each country-year. The coefficients are estimated by system GMM.

Table 7a presents results where it is assumed that only one quarterly lag $(\phi=1)$ matters for the dynamics between inflation and the real exchange rate. Estimation of this VAR specification fail to find any impact from real exchange rate depreciation to higher future inflation. However, inflation does lead to future exchange rate changes in both the IT and non-IT samples. Estimates of VAR models with two lags of the inflation and real exchange rate variables, shown in Table $7 b$, give similar results. Real exchange rate appreciation does not predict future inflation, while inflation is a good predictor of real exchange rate depreciation in the IT sample (but not in the non-IT group).

In sum, there is no evidence that real exchange rates are a good predictor of future inflation and therefore should not in principle enter a forward-looking IT strategy policy equation if inflation is the target for policymakers. The significant responses to real exchange rates in the estimated policy equations, presented in Tables 2, 3, 5 and 6, appear to reflect a separate policy target beyond an inflation target.

We also investigated VAR models including terms-of-trade changes together with real exchange rates and inflation. We considered three alternative measures of the termsof-trade (IMF, IFS and Datastream - see previous discussion in footnote 14). Given the questionable reliability of the terms-of-trade variables, it is perhaps not surprising that none of these measures entered significantly in the VAR equations. These results are not reported for brevity but are available upon request. 


\section{Conclusion}

In this paper we explore the nature of inflation targeting in emerging market and transition economies. IT has become a popular operating procedure for many central banks. This is also true in emerging market and transition economies. In the context of an estimated panel data for 16 emerging markets over 1989Q1 to 2006Q4 (using both IT and non-IT observations), we find clear evidence of a significant and stable response running from inflation to policy interest rates in emerging markets that are following publically announced IT policies. By contrast, we find that non-IT central banks place much less weight on inflation in setting interest rates.

We emphasize that external considerations should play an important role in central bank policy in emerging markets, and more so than in advanced industrial countries. Emerging markets generally have a low level of financial market development, characterized by few instruments and thin trading, which in turn are not able to play a significant role in stabilizing domestic output in the face of external shocks (Aghion et al., 2006). Other considerations also suggest that external factors are more important in emerging markets. To motivate our empirical work, we present a simple model that illustrates the linkages between external vulnerability and the role of the real exchange rate in optimal policy rules.

We test whether emerging markets are following "pure" IT rules, or are also attempting to stabilize real exchange rates. We find strong evidence that IT emerging markets are following a mixed-IT strategy whereby central banks respond to both inflation and real exchange rates in setting policy interest rates. The response to real exchange rates is much stronger in non-IT countries, however, suggesting that policymakers are more constrained in the IT regime - they are attempting to simultaneously target both inflation and real exchange rates and these objectives are not always consistent.

We also find that the response to real exchange rates is strongest in those countries following IT policies that are relatively intensive in exporting basic commodities. This is not surprising since this group is the most vulnerable to terms-oftrade and real exchange rate disturbances. Moreover, the real exchange rate stabilization objective does not appear to be influencing central bank interest rate-setting indirectly 
because it is a good predictor of future inflation (as would be the case if inflation is a good predictor and the central bank is forward looking), i.e. the real exchange rate is not a robust predictor of future inflation in emerging markets. Consistent with out model predictions, real exchange rate stabilization in commodity-intensive countries appears to be related to adverse real output effects associated with real exchange rate volatility.

\section{$\underline{\text { References }}$}

Aghion, Philippe, Philippe Bacchetta, Romain Ranciere and Kenneth Rogoff (2006). "Exchange Rate Volatility and Productivity Growth: The Role of Financial Development.” NBER Working Paper No. 12117 (March).

Aizenman, Joshua (2008). "International reserves management and the current account", pp. 435-474, Current Account and External Financing, Santiago, the Central Bank of Chile, Edited by K. Cowan, S. Edwards and R. Valdés.

Aizenman, Joshua and Daniel Riera-Crichton (2008). "Real exchange rate and international reserves in the era of growing financial and trade integration," Review of Economics and Statistics, Vol. 90. 812-815.

Arellano, M., and S. Bond, 1991. Some Tests of Specification for Panel Data: Monte Carlo Evidence and an Application to Employment Equations. Review of Economic Studies, 58, 277-297.

Ball, Lawrence (1998). "Policy Rules for Open Economies" Reserve Bank of Australia Research Discussion paper number rdp9806; also appeared as NBER Working paper \# 6760 .

Ball, Lawrence and N. Sheridan (2005). "Does inflation targeting matter?" In Monetary Policy under Inflation Targeting, edited by F. Mishkin and K. Schmidt-Hebbel. Santiago: Central Bank of Chile.

Baltagi B H. Econometric analysis of panel data. West Sussex: Wiley \& Sons; 2005.

Breitung, J. (2000). "The Local Power of Some Unit Root Tests for Panel Data." Advances in Econometrics 15, 161-178.

Clarida, Richard H. (2001). "The Empirics of Monetary Policy Rules in Open Economies," International Journal of Finance and Economics 6 (315-323).

Clardia, Richard H., J. Gali, and M. Gertler (1998). "Monetary Policy Rules in Practice: Some International Evidence," European Economic Review (June). 
Clardia, Richard H., J. Gali, and M. Gertler (2000). "Monetary Policy Rules and Macroeconomic Stability: Theory and Evidence," Quarterly Journal of Economics (January).

Clardia, Richard H., J. Gali, and M. Gertler (2001). "Optimal Monetary Policy in Closed versus Open Economies,” American Economic Review (May).

Conçalves, Carlos Eduardo S., and João M. Salles (2008). "Inflation targeting in emerging economies: What do the data say?" Journal of Development Economics 85, $312-318$.

Corbo, Vittorio, Oscar Landerretche and Klaus Schmidt-Hebbel (2001). "Assessing Inflation Targeting After a Decade of World Experience," International Journal of Finance and Economics 6 (343-368).

De Mello, Luiz (2008). Monetary Policies and Inflation Targeting in Emerging Economies (edited volume). OECD (Paris).

De Mello, Luiz and Diego Moccero (2008). "Monetary Policy and Macroeconomic Stability in Latin America: The Cases of Brazil, Chile, Colombia and Mexico." In De Mello (2008), Editor, Monetary Policies and Inflation Targeting in Emerging Economies (edited volume). OECD (Paris).

Dennis, Richard (2003). "Exploring the role of the real exchange rate in Australian monetary policy." The Economic Record 79 (244) 20-38.

Dueker, Michael and Andreas Fischer (2006). "Do Inflation Targeters Outperform Nontargeters?" Federal Reserve Bank of St. Louis Review September/October, pp. 431-450.

Edwards, Sebastian (2006). "The Relationship Between Exchange Rates and Inflation Targeters Revisited,” NBER Working Paper 12163 (April).

Enders (2003). Applied Econometric Time Series. Wiley and Sons.

English, Nelson, and Sack (2002). "Interpreting the Significance of the Lagged Interest Rate in Estimated Monetary Policy Rules." Division of Monetary Affairs, Board of Governors of the Federal Reserve System.

Fraga, A., Goldjfan, I., Minella, A. (2003). "Inflation Targeting in Emerging Market Economies.” NBER Macroeconomics Annual.

Greene, W., 2007. LIMDEP Econometric Modeling Guide Vol. 1. NY: Econometric Software, Inc.

Hausman J, Taylor W. 1981. Panel data and unobservable individual effects. Econometrica 49(6); 1377-1398. 
International Monetary Fund (2005). World Economic Outlook. Washington, D.C.

Johnson, David (2002). "The effect of inflation targeting on the behavior of expected inflation: evidence from an 11 country panel," Journal of Monetary Economics 49, 15211538.

Judson, R.A. and A.L. Owen (1999). "Estimating dynamic panel models: a guide for macroeconomists," Economics Letters 65, 9-15.

Levin, A., C-F. Lin and C-S. Chu (2002). "Unit root tests in panel data: asymptotic and finite-sample properties." Journal of Econometrics 108(1), 1-24.

Love, Inessa and Lea Zicchino (2006). "Financial development and dynamic investment behavior: Evidence from panel VAR." Quarterly Review of Economics and Finance 46, 190-210.

Mishkin, Frederic S. (2004). “Can inflation targeting work in emerging markets?” NBER Working Paper No. 10646 (July).

Mishkin, Frederic S. and Schmidt-Hebbel, Klaus (2007). "Does inflation targeting make a difference?” NBER Working Paper 12876.

Mohanty, M.S. and Marc Klau (2004). "Monetary policy reules in emerging market economies: issues and evidence," BIS Working Paper No. 149 (March).

Nickell, S. (1981). "Bias in panel models with fixed effects”, Econometrica 49, 14171426.

Ravenna, Federico (2008). "The Impact of Inflation Targeting: Testing the Good Luck Hypothesis.” Mimeo. University of California, Santa Cruz, Department of Economics.

Rose, Andrew (2007). “A stable international monetary system emerges: Inflation targeting is Bretton Woods, reversed." Journal of International Money and Finance 26, 663-681.

Schmidt-Hebbel, Klaus and Alejandro Werner (2002). "Inflation Targeting in Brazil, Chile and Mexico: Performance, Credibility, and the Exchange Rate," Economía (Spring), 31-89. 
Table 1 - Descriptive Statistics for Macroeconomic Variables

\begin{tabular}{lcc}
\hline & $\begin{array}{c}\text { IT Sample } \\
(456 \text { obs. })\end{array}$ & $\begin{array}{c}\text { Non-IT Sample } \\
(577 \text { obs. })\end{array}$ \\
\hline Variable: & 1.11 & 1.00 \\
GDP growth (\%) & $(5.93)$ & $(7.84)$ \\
& -0.11 & 0.29 \\
GDP gap (\%) & $(3.86)$ & $(4.62)$ \\
Inflation (\%) & 5.40 & 9.60 \\
& $(4.21)$ & $(9.15)$ \\
Interest rate (\%) & 8.98 & 12.68 \\
& $(6.09)$ & -0.49 \\
Real exchange rate change (\%) & 2.50 & $(13.27)$ \\
& $(5.76)$ & 4.66 \\
Foreign reserve change (\%) & 3.25 & $(22.82)$ \\
\hline Mean and (standard deviation) for all variables. For details, see the data appendix B.
\end{tabular}

Mean and (standard deviation) for all variables. For details, see the data appendix B.

Table 2 - Interest Rate Policy Functions: Baseline Model

\begin{tabular}{|c|c|c|c|c|c|c|}
\hline \multirow[b]{2}{*}{ Variable } & \multicolumn{3}{|c|}{ IT } & \multicolumn{3}{|c|}{ Non IT } \\
\hline & (1) & (2) & (3) & (4) & (5) & (6) \\
\hline $\begin{array}{l}\text { Interest rate }(t- \\
1)\end{array}$ & $\begin{array}{c}0.84 * * * \\
(43.97)\end{array}$ & $\begin{array}{c}0.83 * * * \\
(43.36)\end{array}$ & $\begin{array}{c}0.84 * * * \\
(43.91)\end{array}$ & $\begin{array}{c}0.76 * * * \\
(22.50)\end{array}$ & $\begin{array}{l}0.74 * * * \\
(22.48)\end{array}$ & $\begin{array}{c}0.77 * * * \\
(23.17)\end{array}$ \\
\hline Inflation & $\begin{array}{l}0.22 * \\
(1.86)\end{array}$ & $\begin{array}{c}0.29 * * \\
(2.43)\end{array}$ & $\begin{array}{l}0.22 * \\
(1.86)\end{array}$ & $\begin{array}{c}0.01 \\
(0.72)\end{array}$ & $\begin{array}{c}0.15 * * * \\
(5.08)\end{array}$ & $\begin{array}{c}0.01 \\
(0.62)\end{array}$ \\
\hline GDP gap & $\begin{array}{c}0.03 \\
(1.05)\end{array}$ & $\begin{array}{l}0.05 \\
(1.55)\end{array}$ & $\begin{array}{c}0.03 \\
(1.05)\end{array}$ & $\begin{array}{c}0.02 \\
(0.37)\end{array}$ & $\begin{array}{c}0.03 \\
(0.62)\end{array}$ & $\begin{array}{c}0.02 \\
(0.52)\end{array}$ \\
\hline RER change & & $\begin{array}{c}0.07 * * * \\
(3.46)\end{array}$ & & & $\begin{array}{c}0.13 * * * \\
(5.78)\end{array}$ & \\
\hline $\begin{array}{l}\text { Reserve } \\
\text { change }\end{array}$ & & & $\begin{array}{c}0.09 \\
(0.05) \\
\end{array}$ & & & $\begin{array}{c}-0.06 * * * \\
(-3.95)\end{array}$ \\
\hline Observations & 387 & 387 & 387 & 472 & 472 & 472 \\
\hline Adjusted-R ${ }^{2}$ & 0.76 & 0.77 & 0.76 & 0.79 & 0.80 & 0.73 \\
\hline F-test & 272.10 & 206.89 & 203.60 & 177.55 & 151.01 & 141.35 \\
\hline
\end{tabular}

Note: Dependent variable: money-market nominal interest rates. Panel fixed-effects estimation. The associated t- statistics are noted below each estimated coefficient. $* * *, *, *$ indicate the significance level at 1,5 , and 10 percent, respectively. 
Table 3 -Policy Functions: Real Exchange Rates and Trade Openness

\begin{tabular}{lccc|ccc}
\hline & \multicolumn{3}{c}{ IT } & \multicolumn{3}{c}{ Non IT } \\
Variable & $(1)$ & $(2)$ & $(3)$ & $(4)$ & $(5)$ & $(6)$ \\
\hline \multirow{2}{*}{ Interest rate (t-1) } & $0.8^{* * *}$ & $0.83^{* * *}$ & $0.83^{* * *}$ & $0.82^{* * *}$ & $0.78^{* * *}$ & $0.78^{* * *}$ \\
& $(39.64)$ & $(37.37)$ & $(37.38)$ & $(26.26)$ & $(24.22)$ & $(25.08)$ \\
Inflation & $0.21^{*}$ & $0.26^{* *}$ & $0.26^{* *}$ & $0.07 * *$ & $0.11^{* * *}$ & $0.10^{* * *}$ \\
& $(1.65)$ & $(2.06)$ & $(2.06)$ & $(2.06)$ & $(4.40)$ & $(3.75)$ \\
GDP gap & 0.03 & 0.04 & 0.04 & 0.05 & $0.07 *$ & $0.07 * *$ \\
& $(1.01)$ & $(1.31)$ & $(1.32)$ & $(1.42)$ & $(1.90)$ & $(2.13)$ \\
RER change & & $0.10^{* *}$ & $0.10^{* *}$ & & $0.17 * * *$ & $0.16^{* * *}$ \\
RER change * & & $(2.21)$ & $(2.31)$ & & $(3.74)$ & $(3.50)$ \\
trade openness & & -0.04 & -0.05 & & $-0.11^{* *}$ & $-0.11^{* *}$ \\
Reserve change & & $(-0.45)$ & $(-0.84)$ & & $(-1.98)$ & $(-2.07)$ \\
& & & 0.01 & & & $-0.06 * * *$ \\
Observations & 355 & 355 & 355 & 415 & 415 & 415 \\
Adjusted-R2 & 0.83 & 0.84 & 0.84 & 0.84 & 0.84 & 0.85 \\
F-test & 594.44 & 365.97 & 304.55 & 143.51 & 155.73 & 140.83 \\
\hline
\end{tabular}

Note: Dependent variable: money-market nominal interest rate. Panel fixed-effects estimation. The associated $\mathrm{t}$ - statistics are noted below each estimated coefficient. $* * *, * *, *$ indicate the significance level at 1,5 , and 10 percent, respectively.

Table 4 - Descriptive statistics: Commodity Intensive and Non-Intensive IT groups

\begin{tabular}{lcc} 
Variable & $\begin{array}{c}\text { IT Commodity } \\
(116 \text { obs. })\end{array}$ & $\begin{array}{c}\text { IT Non-Commodity } \\
(271 \text { obs.) }\end{array}$ \\
\hline \multirow{2}{*}{ GDP growth (\%) } & 1.03 & 1.14 \\
& $(5.14)$ & $(6.24)$ \\
GDP gap (\%) & 0.28 & -0.29 \\
& $(3.32)$ & $(3.98)$ \\
Inflation (\%) & 6.75 & 4.83 \\
& $(5.26)$ & $(3.53)$ \\
Interest rate (\%) & 12.69 & 7.41 \\
& $(7.36)$ & $(4.65)$ \\
Real exchange rate change (\%) & 2.82 & 2.37 \\
& $(6.79)$ & $(5.27)$ \\
Foreign reserve change $(\%)$ & 3.14 & $(7.48)$ \\
\hline
\end{tabular}

Commodity IT countries include Brazil, Colombia, Mexico, and Peru. The non-commodity IT countries are Czech Republic, Hungary, Israel, Korea, Philippines, Poland and Thailand. 
Table 5 - IT Policy Functions: Commodity-intensive and Noncommodity intensive groups

\begin{tabular}{lcc}
\hline & IT Commodity & IT Non-commodity \\
\hline Interest rate $(\mathrm{t}-1)$ & $0.70^{* * *}$ & $0.85^{* * *}$ \\
& $(13.11)$ & $(47.38)$ \\
Inflation & $0.83^{* *}$ & -0.12 \\
& $(2.14)$ & $(-1.37)$ \\
GDP gap & 0.07 & 0.03 \\
& $(0.71)$ & $(1.38)$ \\
RER change & $0.11^{*}$ & $0.05^{* * *}$ \\
\hline Observations & $(1.82)$ & $(3.44)$ \\
Adjusted-R & 116 & 271 \\
F-test & 0.74 & 0.93 \\
\hline
\end{tabular}

Note: Dependent variable: money-market interest rates. Panel fixed-effects estimation. The associated $\mathrm{t}$ - statistics are noted below each estimated coefficient. $* * *, * *, *$ indicate the significance level at 1,5 , and 10 percent, respectively.

Table 6 - Policy Funciton Robustness Tests: Inflation Gaps from Target and H-T

\section{Estimation}

\begin{tabular}{lcccc}
\hline \multirow{2}{*}{ Variables: } & \multicolumn{2}{c}{ IT Commodity } & \multicolumn{2}{c}{ IT Non-commodity } \\
& $(1)$ & $(2)$ & $(3)$ & $(4)$ \\
\hline \multirow{2}{*}{ Interest rate (t-1) } & $0.82^{* * *}$ & $0.82^{* * *}$ & $0.81 * * *$ & $0.79 * * *$ \\
& $(20.20)$ & $(19.76)$ & $(32.39)$ & $(30.02)$ \\
Inflation gap from target & $0.88^{* * *}$ & $0.89^{* * *}$ & -0.10 & -0.11 \\
& $(3.06)$ & $(2.98)$ & $(0.92)$ & $(1.06)$ \\
GDP gap & $0.17^{* *}$ & $0.15^{*}$ & $0.17 * *$ & 0.00 \\
& $(2.00)$ & $(1.76)$ & $(1.00)$ & $(0.08)$ \\
RER change & $0.07^{* *}$ & & $0.08^{* * *}$ & \\
Reserve change & $(2.08)$ & & $(4.18)$ & \\
& & -0.04 & & $0.03 * *$ \\
Observations & 64 & $(1.23)$ & & $(2.21)$ \\
Adjusted-R & & 64 & 172 & 172 \\
\hline
\end{tabular}

Note: Dependent variable: money-market nominal interest rate. Hausman-Taylor estimation. The associated $\mathrm{t}$ - statistics are noted below each estimated coefficient. $* * *, * *, *$ indicate the significance level at 1,5 , and 10 percent, respectively. 
Table 7a - Panel-VAR for RER and CPI (one lag)

\begin{tabular}{lcc|cc}
\hline & \multicolumn{2}{c|}{ IT } & \multicolumn{2}{c}{ Non-IT } \\
Variable & Inflation & RER change & Inflation & RER change \\
\hline \multirow{2}{*}{ Inflation (t-1) } & 0.36 & 0.58 & 0.71 & -0.55 \\
& $(4.53)$ & $(1.73)$ & $(.37)$ & $(-1.80)$ \\
RER change (t-1) & 0.01 & 0.32 & 0.02 & 0.10 \\
& $(0.86)$ & $(3.23)$ & $(0.87)$ & $(1.99)$ \\
\hline Observations & \multicolumn{3}{c}{432} & \multicolumn{2}{c}{564} \\
\hline
\end{tabular}

Note: The associated t- statistics are noted below each estimated coefficient. Coefficients and t-statistics obtained by system GMM estimation.

Table 7b - Panel-VAR for RER and CPI (2 lags)

\begin{tabular}{lcc|cc}
\hline & \multicolumn{2}{c|}{ IT } & \multicolumn{2}{c}{ Non-IT } \\
Variable & Inflation & RER change & Inflation & RER change \\
\hline \multirow{2}{*}{ Inflation (t-1) } & 0.25 & 0.55 & 0.54 & -0.05 \\
& $(3.31)$ & $(1.74)$ & $(1.61)$ & $(-0.15)$ \\
RER change (t-1) & 0.01 & 0.45 & 0.03 & 0.41 \\
& $(0.93)$ & $(7.81)$ & $(0.52)$ & $(3.75)$ \\
Inflation (t-2) & 0.27 & 0.05 & 0.23 & -0.27 \\
& $(4.67)$ & $(0.19)$ & $(0.98)$ & $(-1.08)$ \\
RER change (t-2) & 0.003 & 0.11 & -0.01 & 0.02 \\
& $(0.45)$ & $(-2.08)$ & $(-0.41)$ & $(0.56)$ \\
\hline \multirow{2}{*}{ Observations } & \multicolumn{2}{|c}{5} \\
\end{tabular}

Note: The associated t- statistics are noted below each estimated coefficient. Coefficients and t-statistics obtained by system GMM estimation.

Table 8 - Panel-VAR for Inflation, RER and TOT(IMF) Regressions

\begin{tabular}{lccc|ccc}
\hline Variable & Inflation & $\begin{array}{c}\text { RER } \\
\text { change }\end{array}$ & $\begin{array}{c}\text { TOT } \\
\text { change }\end{array}$ & Inflation & $\begin{array}{c}\text { RER } \\
\text { change }\end{array}$ & $\begin{array}{c}\text { TOT } \\
\text { change }\end{array}$ \\
\hline Inflation (t-1) & 0.36 & 0.54 & -0.07 & 0.71 & -0.55 & 0.004 \\
RER change & $(4.59)$ & $(1.63)$ & $(-0.99)$ & $(2.37)$ & $(-1.80)$ & $(1.22)$ \\
(t-1) & 0.01 & 0.31 & -0.003 & 0.02 & 0.10 & 0.002 \\
TOT change & $(0.94)$ & $(3.15)$ & $(-0.34)$ & $(0.88)$ & $(2.00)$ & $(0.71)$ \\
$(\mathrm{t}-1)$ & $(0.03$ & -0.25 & 0.85 & -0.09 & -0.12 & 0.77 \\
\hline Observations & $(-1.44)$ & $(13.91)$ & $(-1.01)$ & $(-0.70)$ & $(15.04)$ \\
\hline
\end{tabular}

Note: The associated t- statistics are noted below each estimated coefficient. Coefficients and t-statistics obtained by system GMM estimation. 


\section{Appendix A: Inflation targeting in the open economy: economic structure and the real exchange rate.}

This Appendix illustrates conditions that may lead the policy maker to adopt IT rule that would include exchange rate in the policy rule. We focus on the simplest set up that illustrates this point. A well know benchmark paper is Ball (1998), studying inflation targeting in the open economy, where setting the interest rate and the exchange rate impacts future output and inflation. Assuming that the inflation target and potential output ( $\tilde{\pi}$ and $\tilde{y}$, respectively) are exogenously given, the IT rule is designed to minimize the loss function [equivalently, minimizing $L=V(\pi-\tilde{\pi})+\mu V(y-\tilde{y})$ ]: $L=V(\pi)+\mu V(y)$

where $y$ is the log of real output (measured as deviations from average levels), $\pi$ is inflation, $\mu$ is the relative weighted attached to output versus inflation objectives, and $\mathrm{V}(\mathrm{x})$ is the variance of $\mathrm{x}$. In Ball's set up, the exchange rate (e) plays a role in the IT setting if it affects inflation or output, leading to the conclusion that "...if the authorities have modeled the economy correctly (and, in doing so, have incorporated the effects of $e$ on $\pi$ and $y$ ), there is no need to include an exchange rate term in (the IT) equation" [see Edwards (2006)]. Edwards (2006) also notes that "If, however, there is a lagged response of inflation and output to exchange rate changes, the central bank may want to preempt their effect by adjusting the policy stance when the exchange rate change occurs, rather than when its effects on $\pi$ and $y$ are manifested."

In this Appendix we show that the role of the exchange rate and economic structure is more involved in circumstances where potential output is affected by exchange rate volatility. ${ }^{21}$ To illustrate this point, suppose that potential output, $\tilde{y}$, depends negatively on exchange rate volatility, $\tilde{y}=\tilde{y}(V(e)) ; \quad \tilde{y}^{\prime}<0$. The modified loss function facing the policy maker would be

$$
\widehat{L}=V(\pi)+\mu V(y)+\phi V(e)
$$

\footnotetext{
${ }^{21}$ Aghion et al. (2006) showed that exchange rate volatility reduces potential output (or output growth rate) in developing countries, attributing it to financial channels. The adverse effect of volatility may be the outcome of increasing the expected cost of funds in circumstances where agency and contract enforcement costs are prevalent, the financial system is shallow, and trade openness is significant.
} 
where $\phi$ reflects the welfare cost associated with the drop in potential output induced by exchange rate volatility. To simplify the discussion, we modify Ball's model into a set up where the adjustment to shocks happens within the period, without persistence. ${ }^{22}$ Applying Ball's notation, the base system we consider is:
a. $y=-\beta r-\delta e+\varepsilon$
b. $\pi=\alpha y-\gamma e+\eta$
c. $e=\theta r+v$

where all parameters are positive, all variables are measured as deviations from average levels, $y$ is the deviation of output from the trend "potential output," $r$ is the real interest rate, $e$ is the real exchange rate (a higher $e$ means appreciation), $\pi$ is inflation, and $\varepsilon, \eta$, and $v$ are white-noise shocks. Equation (A3a) is an open-economy IS curve. Output depends on lags of the real interest rate and the real exchange rate, and a demand shock. Equation (A3b) is an open-economy Phillips curve. The change in inflation depends on output's deviations from "potential output", the exchange rate, and a shock. The change in the exchange rate affects inflation because it is passed directly into import prices. Equation (A3c) links the interest rate and the exchange rate, assuming that a rise in the interest rate makes domestic assets more attractive, leading to an appreciation. The shock $v$ reflects other considerations impacting the exchange rate (investor confidence, foreign interest rates, risk premium, etc).

Suppose that the central bank chooses the real interest rate $r$ applying a modified inflation targeting rule:

$r=a \pi+b y+c e$

Applying (A4) to (A3), we solve for the implied inflation, output and the exchange rate volatility as a function of the shocks and the IT parameters $\langle a, b, c\rangle$. It can be shown that

a. $V(e)=\left[(b+a \alpha)^{2} \theta^{2} V(\varepsilon)+[1+\beta(b+a \alpha)]^{2} V(\nu)+(a \theta)^{2} V(\mu)\right] / D$

b. $V(y)=\left[(1+\theta(a \alpha-c))^{2} V(\varepsilon)+[\beta(a \alpha-c)-\delta]^{2} V(v)+(a B)^{2} V(\mu)\right] / D$

c. $V(\pi)=\left[(\alpha(1-c \theta)-b \gamma \theta)^{2} V(\varepsilon)+[\beta(\alpha c+b \gamma)+\delta \alpha+\gamma]^{2} V(v)+(1-c \theta+b B)^{2} V(\mu)\right] / D$

where $D=[1+B(b+a \alpha)+\theta(a \alpha-c)]^{2}, B=\beta+\delta \theta$.

${ }^{22}$ This may be the case if all the nominal contracts are re-set at the end of each period. 
Feeding (A5) to the loss function (A2), the optimal IT rule is inferred by minimizing the loss resultant function [i.e., the $<a, b, c>$ that minimize the loss function (A2)].

Note that (A5a) implies that a negative weight on the exchange rate parameter $(\mathrm{c}<0)$ tends to reduce exchange rate volatility. This will be the with a policy rule where exchange rate depreciation would increase the interest rate. Indeed, simulations confirm that greater weight attached to reducing the costs of exchange rate volatility tends to increase the responsiveness of the interest rate rule to exchange rate depreciation (further lowering c), with sizable impact on the loss function. Figure A1 overview this effect. The size of the welfare gain associated with changing $c$ can be shown to be larger; the greater is the welfare cost of exchange rate volatility, $\phi$. Comparing the two panels of Figure A 1 suggests that the cross effect of changing $c$ on $<a, b>$ are small (they can be shown to be ambiguous, depending on the economic structure).
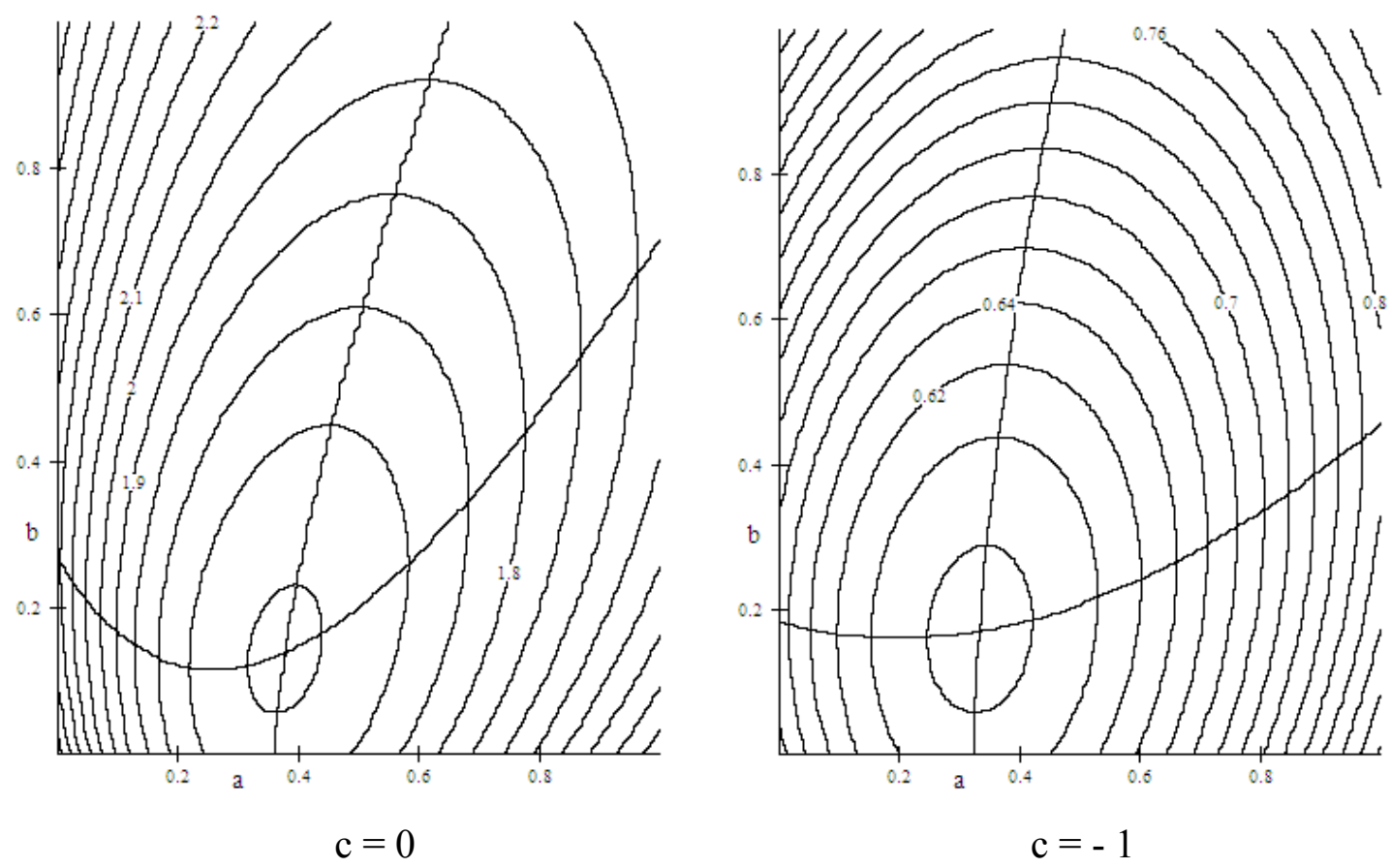

Figure A1: On the gains of policy rule responding to exchange rate changes.

The simulation assumes:

$V(v)=V(\varepsilon)=1 ; V(\mu)=0.3 ; \phi=1 ; B=1, \theta=2, \delta=0.2, \beta=0.6, \alpha=0.4$

The contours show the loss function. The two lines correspond to $\langle a, b>$ configurations associated with first order conditions for optimal values of $a$ (the steeper curve) and $b$ (the $u$ shaped curve), respectively, for a given value of $c$. The left panel corresponds to $c$ $=0$, the right panel corresponds to $c=-1$. 


\begin{tabular}{lcl} 
Appendix B: Emerging Markets Sample & \\
\hline IT countries & $\begin{array}{c}\text { Start of Inflation } \\
\text { Targeting Regime }\end{array}$ & Non-IT countries \\
\hline Brazil & $1999 Q 1$ & Argentina \\
\hline Colombia & $1999 Q 1$ & Indonesia \\
\hline Czech Republic & $1998 Q 1$ & Jordan \\
\hline Hungary & $2001 Q 1$ & Malaysia \\
\hline Israel & $1992 Q 1$ & Morocco \\
\hline Korea & $1998 Q 1$ & \\
\hline Mexico & $1999 Q 1$ & \\
\hline Peru & $1994 Q 1$ & \\
\hline Philippines & $2001 Q 1$ & \\
\hline Poland & $1998 Q 1$ & \\
\hline Thailand & $2000 Q 1$ & \\
\hline Sorce for &
\end{tabular}

Source for IT start dates: Mishkin and Schmidt-Hebbel (2007)

\begin{tabular}{lll} 
Appendix C: Data Details & Source \\
\hline Variable & Definition & $\begin{array}{l}\text { Authors' calculations. From real GDP } \\
\text { or, where missing, production indices. }\end{array}$ \\
\hline GDP growth & $\begin{array}{l}\text { GDP growth relative to trend } \\
\text { calculated with a Hodrick- } \\
\text { Prescott filter }\end{array}$ & $\begin{array}{l}\text { Authors' calculations. A positive number } \\
\text { is defined as above trend growth. }\end{array}$ \\
\hline GDP gap & Time difference of log CPI & Authors' calculations from CPI. \\
\hline $\begin{array}{l}\text { Inflation } \\
\text { Inflation gap from } \\
\text { target }\end{array}$ & $\begin{array}{l}\text { Log CPI minus the log of the } \\
\text { target rate }\end{array}$ & $\begin{array}{l}\text { Target rates obtained from national } \\
\text { Central Bank sources. }\end{array}$ \\
\hline $\begin{array}{l}\text { Real exchange } \\
\text { rate change }\end{array}$ & $\begin{array}{l}\text { Time difference of log RER } \\
\text { Authors' calculations using IFS real } \\
\text { Trade Openness }\end{array}$ & $\begin{array}{l}\text { Autfective exchange rate data and where } \\
\text { missing nominal exchange rates and CPI } \\
\text { from the IFS. An increase in the real } \\
\text { exchange rate is a real depreciation. }\end{array}$ \\
\hline $\begin{array}{l}\text { Reserve change } \\
\text { Time difference of log foreign }\end{array}$ & \\
\hline $\begin{array}{l}\text { Exchange rate } \\
\text { regime }\end{array}$ & $\begin{array}{l}\text { XR regime for both de jure and } \\
\text { de facto regimes }\end{array}$ & \\
\hline
\end{tabular}

All data is from the International Monetary Fund's International Finance Statistics. 


\begin{tabular}{|c|c|c|c|c|}
\hline & \multicolumn{2}{|c|}{ IT } & \multicolumn{2}{|c|}{ Non-IT } \\
\hline & LLC & Breitung & LLC & Breitung \\
\hline GDP gap & 6.69 & $-3.45 * *$ & 2.37 & $-3.37 * *$ \\
\hline Inflation & $-9.09 * *$ & $-1.56^{*}$ & 3.50 & $-3.00 * *$ \\
\hline Interest rate & $-12.29 * *$ & 0.58 & $-2.46^{* *}$ & -0.72 \\
\hline $\begin{array}{l}\text { Real exchange rate } \\
\text { change }\end{array}$ & $-11.77 * *$ & $-7.88 * *$ & $-12.66^{* *}$ & -1.21 \\
\hline \multicolumn{5}{|c|}{$\begin{array}{l}\text { Note: The results are based on Levin, Lin and Chu (2002) and Breitung (2000) tests. **, * indicates the } \\
\text { rejection of the common unit root null hypothesis at } 5 \% \text { and } 10 \% \text { significance level, respectively. As is true } \\
\text { for all other panel unit root tests, these tests should be interpreted with caution since both tests assume a } \\
\text { common process. Any deviation from that assumption will entail a rejection of the null, even if some } \\
\text { country time-series do have a unit root. Individual country unit root tests will have weak power with } \\
\text { quarterly data. For a summary of the difficulties with panel unit root tests, see Enders (2003, chapter } 4.11)\end{array}$} \\
\hline
\end{tabular}

\section{Appendix E: Descriptive Statistics for TOT Variable}

\begin{tabular}{lcc}
\hline Variable & IT & Non-IT \\
\hline Terms of Trade change (\%) & 0.04 & -0.09 \\
(IMF data) & $(1.65)$ & $(1.18)$ \\
& {$[456]$} & {$[585]$} \\
Terms of Trade change (\%) & 0.34 & 0.07 \\
(IFS data) & $(4.11)$ & $(7.88)$ \\
& {$[268]$} & {$[354]$} \\
Terms of Trade change (\%) & 0.34 & 0.57 \\
(Datastream data) & $(4.10)$ & $(5.88)$ \\
& {$[299]$} & {$[191]$} \\
\hline
\end{tabular}

Correlations of TOT Variables

TOT(IMF)-TOT(IFS): $0.03 \quad$ TOT(IMF)-TOT(DS): $0.08 \quad$ TOT(DS)-TOT(IFS): 0.13

Mean, (standard error), [observations]. For details, see the data appendix. 